"a great opportunity" to expand plant biology.

At the University of Arizona, the director of their herbarium, Lucinda McDade, is leaving to become herbarium curator at the Academy of Natural Sciences in

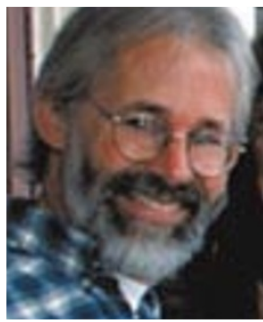

Donoghue: offered

jobs at both Harvard and Yale.
Philadelphia.

Eugene Sander, a biochemist who is dean of Arizona's College of Agriculture, says McDade had secured two National Science Foundation grants to modernize Arizona's collection of desert flora from the southwest

United States and northwest Mexico. "Our university is losing a fine scientist who will be difficult to replace," says Sander.

The University of Alaska is having trouble recruiting a director for its herbarium of high-latitude specimens, which is important for research on global warming. According to David McGuire, chairman of the Alaska search committee, when the university advertised last July for an assistant professor, it received only 15 applications, half of what was desired; and that number was achieved after pleas to herbarium directors around the nation.

Alaska is interviewing three candidates, says evolutionary biologist McGuire. Beginning today, 11 November, the American Institute of Biological Sciences, an umbrella organization for 55 biological societies, will hold a summit in Virginia for organization presidents. It will address a range of planning issues, including the availability of plant systematists, says the institute's president, Gregory Anderson, a University of Connecticut botanist.

Approximately 150 university departments of ecology and evolutionary biology include plant systematists, Anderson says. About 30 to 50 students may graduate annually, with half seeking work at universities. Consideration should be given to increasing the number of trained plant systematists - particularly those with molecular biology skills - to balance supply and demand, he says.

It is important to address this balance soon, because many plant systematists are on the verge of retirement - for example Shirley Graham, a professor at Kent State University in Ohio and president of the American Society of Plant Taxonomists.

"My husband and I are the only botanists in our department of 25 faculty, and we are both a year from retirement," says Graham. "Botanists have retired and been replaced by other disciplines. Now we have to rethink what constitutes a good programme in botany." Rex Dalton

\title{
Publishing group offers peer review on PubMed Central
}

Paris

The Current Science Group is to establish a new publishing house dedicated to providing peer review and other services for PubMed Central, the free repository for life-science papers that is due to be launched early in the new year by the US National Institutes of Health.

The new venture, called BioMed Central, will be established as a separate company within the group, with an initial staff of around 20. Other parts of the Current Science Group will contribute to the venture, says Vitek Tracz, the group's chief executive officer. "We have a tradition of working together as smallish, independent units with little bureaucracy, and we like it that way."

The new company, whose 'under construction' website can be viewed at http://www.biomedcentral.com/, is intended to provide a "large multidisciplinary peerreview mechanism”, sitting on top of PubMed Central that "would be equivalent to thousands of journals", says Tracz. "It is the most exciting and the most important publishing initiative I have got myself into."

On acceptance, papers submitted to Bio-
Med Central would be deposited in PubMed Central, where they would be available free to all. Tracz believes that it will be feasible to give this primary literature away, and make money from a mix of advertising, sponsorship, e-commerce and subscription to editorial material such as news and reviews.

A similar logic is being followed by a venture launched last month by the Community of Science, a private US company that gives researchers information about funding opportunities and other activities (see Nature 401, 516; 1999).

Many publishers remain sceptical whether such Internet business models largely untested in science publishing — will provide enough revenue to support quality publishing operations (see page 115).

This is partly a defensive reflex - some publishers have been making what many consider to be excessive profits (see Nature 397, 195-200; 1999). But there are genuine concerns among publishers and scientific societies that, if change is too rapid and ill-considered, the baby of quality literature might be thrown out with the bathwater.

\section{Ukraine denies arresting biologist}

\section{London}

The Ukrainian government last week denied accusations that a prominent marine biologist, Sergei Piontkovski, had been arrested and charged with sending secret information abroad and handling foreign currency illegally.

The statement was made by the first deputy foreign minister of Ukraine in response to concerns expressed by the European Commission over the arrest and detention of research workers from the Institute of Biology of the Southern Seas (IBSS) in Sebastopol (see Nature 401, 835 \& 402, 6; 1999).

Piontkovski and colleagues are back at work, but reports suggest that they still face charges, and Piontkovski's trial is scheduled for later this month. The security service continues to hold IBSS computers and documents. A spokesperson for the European aid programme INTAS said the Ukrainian Ministry of Science had been supportive in trying to persuade authorities of the innocence of IBSS staff. "It is clear to the authorities that Piontkovski was arrested on non-legal grounds," said a spokesperson.

Grants from INTAS and the British government - on biodiversity — have been the focus of inquiries by the security services. Last week, Yuri Tokarev, deputy director of the IBSS, who also faces criminal charges, said charges related to bioluminescence studies. This could be connected with the awarding of a grant by the US Office of Naval Research (ONR) to the Plymouth Marine Laboratory in the United Kingdom in August, for work with which Piontkovski is involved to create a database on bioluminescence in the oceans.

A US Navy spokesperson said: "This project is part of an international effort with broad participation and is expected to increase knowledge of the basic scientific properties of the oceans, including the distribution and abundance of bioluminescent animals and plants."

He said it would be "inappropriate" for the navy to comment on the alleged arrest, and that ONR was a "leading supporter of oceanographic research, and sponsors many unclassified basic research and datagathering projects around the world". The head of IBSS's laboratory of biophysical ecology last week said his was the only laboratory in the former Soviet Union dealing with bioluminescence in the sea. 